\title{
REVIEW
}

\section{Tales from topographic oceans: topologically associated domains and cancer}

\author{
Moray J Campbell \\ Division of Pharmaceutics and Pharmaceutical Chemistry, College of Pharmacy, The Ohio State University, Columbus, Ohio, USA \\ Correspondence should be addressed to M J Campbell: Campbell.1933@osu.edu
}

\begin{abstract}
The 3D organization of the genome within the cell nucleus has come into sharp focus over the last decade. This has largely arisen because of the application of genomic approaches that have revealed numerous levels of genomic and chromatin interactions, including topologically associated domains (TADs). The current review examines how these domains were identified, are organized, how their boundaries arise and are regulated, and how genes within TADs are coordinately regulated. There are many examples of the disruption to TAD structure in cancer and the altered regulation, structure and function of TADs are discussed in the context of hormone responsive cancers, including breast, prostate and ovarian cancer. Finally, some aspects of the statistical insight and computational skills required to interrogate TAD organization are considered and future directions discussed.
\end{abstract}

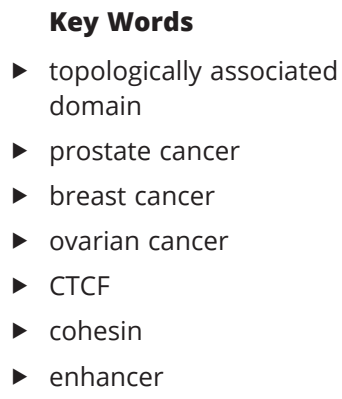

\section{Topologically associated domains in gene regulation}

\section{The 3D organization of the nucleus}

The seventeenth century development of microscopes enabled observation of biological structures, such as the eye of a fly, at a previously unprecedented level of detail. These observations led to Matthias Schleiden and Theodor Schwann in 1838 to spearhead the development of cell theory (reviewed in; Franke 1988), which proposed that cells were the basic unit of structure of all organisms, and that they were produced form preexisting cells. With ever-increasing microscopic power, cells were revealed to contain numerous sub-structures, both in the cytoplasm and the nucleus, and that indeed the nucleus was a functionally vital structure within the cell. For example, although there is considerable variability in the size, shape and longevity of cells in the human body, the nucleus they contain is remarkably consistent, being approximately
$6 \mu \mathrm{M}$ in diameter, representing approximately $10 \%$ of the cell volume. Of course, of key importance, the nucleus contains the same genetic material.

Given its constant shape and ubiquitous nature, the nucleus has been the subject of intense study for the last several centuries, which led to the identification of substructures and organization. For example, analyses of the cells of sea urchin and other readily accessible model organisms revealed that the nucleus which had previously been perceived as a dark sea of unknown functions was in fact richly detailed with sub-features. These newly identified structures included the so-called 'A/B regions' which contained the so-called 'active' central part of the nucleus and the $\mathrm{B}$ inactive region at the periphery; the nucleolus; various 'speckled features' including the 
olfactory region; and chromosomal territories. Thus, the nucleus actually contained structural components that were not static, but instead the chromosomes and other features moved on currents through the cell cycle and during differentiation. Determining how these nuclear structures and movements relate to gene regulatory processes has been a central research focus for much of the last 100 years.

Charting the topography of the nucleus was profoundly catalyzed by the publication in 2001 of the draft human genome (Olivier et al. 2001, Wolfsberg et al. 2001, Wright et al. 2001), which ushered in the genomics era of research. Genomic-centered research necessitated and was further catalyzed by the development of bioinformatics and statistical approaches, combined with sequencing technologies of ever-increasing precision and throughput. These statistical approaches, computational developments and technology advancements all combined to develop an unprecedented understanding of the content and structure of the nucleus, and the diversity and regulation of nucleic acids. Arising from these interdisciplinary efforts has been the concept called the 3D genome (reviewed in Gibcus \& Dekker 2013, Rowley \& Corces 2018, Spielmann et al. 2018).

\section{Identification of topologically associated domains}

Following on from the discovery of these physical structures within the nucleus and their movements, many workers focused on understanding gene regulation mechanisms with the goal to understand how genic features, such as gene enhancer regions bring about coordinated gene expression, and of which gene(s).

A well-studied and revealing gene regulatory scenario has been the analyses of the immunoglobulin (IgG) region that includes the beta and gamma-globin genes; $\beta$-globulin is initially transcribed in the fetal liver but becomes fully active during erythropoiesis in the adult bone marrow, whereas $\gamma$-globulin is strongly expressed in fetal liver and very lowly expressed in the adult bone marrow. The IgG region has become a wellexamined model to investigate enhancer-gene regulation relationships, due to their essential functions and disruptions in various leukemias (reviewed in Unkeless 1989, Heijnen \& van de Winkel 1997, Chenoweth et al. 2015). Initial studies reasoned that open chromatin sites within the locus, identified by DNAase hypersensitivity would be accessible to transcription factors and were used to identify the key features required for these dynamic gene expression patterns (Blom van Assendelft et al. 1989,
Hanscombe et al. 1991). Subsequently, studies by Fraser and colleagues extended this concept to reveal that enhancer-gene communication existed across large genomic distances (Dillon et al. 1997, Carter et al. 2002).

The concept of inter- and intra-chromosomal functional interactions was supported by earlier studies in sea urchin that had observed chromosomal co-segregation and physical contact in an ordered manner (Kojima 1960, Wang \& Taylor 1979, Arceci \& Gross 1980). Subsequently, non-homologous chromosomal contacts were identified in the ribosome, which includes $~ 300$ genes in the nucleolus from five different chromosomes. Similarly, hundreds of olfactory genes from multiple chromosomes converge often in heterochromatic loci and are coordinately regulated (Gilad \& Lancet 2003, Olender et al. 2016).

However, to catalog the potential for large-scale and dynamic interactions within and between chromosomes required new technologies and development of statistical approaches. Specifically, chromosome cross-talk was comprehensively addressed by the development of chromatin capture techniques (reviewed in Denker \& de Laat 2016, Chang et al. 2018, Fu et al. 2019). These approaches leverage the possibility of capturing the physical proximity of widely spaced regions and applying next-generation sequencing technologies to define the location and extent of these associations.

In this manner, and with improvements in computational power and refinements to statistical modeling, ever more complex maps of chromatin loop formation were generated. In turn this gave rise to the concept that these loop structures were contained within topologically associated domains (TADs) (Dixon et al. 2012, Nora et al. 2012, de Laat \& Duboule 2013). In parallel, other approaches revealed that lamin-associated domains (LADs) were also organized and were associated with movement of chromosomes to the outer lamina membrane of the nucleus. Remarkably, TAD structure appears to be essentially invariant across cells within a given organism, and in humans they range from $\sim 100 \mathrm{~kb}$ to $\sim 1 \mathrm{mb}$, and across cell types there are somewhere between 500 and 1500 TADs that can cover much of the genome. However, between cell types there is a significant variation in the activity of the contents of each TAD (reviewed in Roy et al. 2018, Krumm \& Duan 2019, Wang et al. 2019).

There is evidence for TAD structure to be conserved between Drosophila, mice and humans. Indeed, TAD structure is highly conserved over syntenic chromosomal regions and it is tempting to speculate that over evolution this has influenced how evolutionary pressures have (c) 2019 Society for Endocrinology Published by Bioscientifica Ltd. Printed in Great Britain 
selected genomic changes within and outside TADs as alterations are more common outside of TADs than inside, suggesting they are selected against when they occur (Harmston et al. 2017, Gong et al. 2018, Krefting et al. 2018).

The precise function and significance of TAD structure is still a topic of significant investigation but a consensus is that this is the unit of organization for the genome and has arisen as it gives a number of biological advantages. Namely, it allows for coordination of gene regulation programs and the integration of transcriptional signals (Dixon et al. 2016) (Fig. 1A). That is there are many more enhancers across the genome than there are genes to be regulated; it is estimated that there are potentially as many as ten enhancers for every gene and that these enhancers can be often exceedingly distal from target genes (Schmidl et al. 2014, Murakawa et al. 2016, Ron et al. 2017, Furlong \& Levine 2018). By enclosing multiple genes within a regulatory TAD region, promiscuous regulation is limited, and also for those genes within the TAD coordinated regulation is more readily established. It has also emerged that TADs are hierarchical and contain smaller regions of looping within them (Hansen et al. 2018, Racko et al. 2019).
Thus, in general terms the TAD structure allows for the coordinated regulation of genes, although as with all complex biological phenomena, there is diversity in the level of organization and response. That is, the TAD structure is not the mammalian equivalent of a bacterial operon. There are strong examples of co-regulated genes within a TAD, and specific TADs are beginning to be characterized by investigators. For example, the regulation of $\sim 1 \mathrm{Mb}$ TAD on chr 5 containing the protocadherins has emerged as a well-investigated example (Dixon et al. 2012, Nora et al. 2012, Symmons et al. 2014, Jiang et al. 2017). Whilst these individual loci are informative, it is clear there remain areas of ambiguity in terms of how TADs are formed and regulated that suggest other mechanisms participate in gene regulation (Rodriguez-Carballo et al. 2017, Barutcu et al. 2018, Luo et al. 2018).

Therefore, the view has emerged that the TAD can be considered as the functional unit of the genome being strongly conserved between cell types. A significant focus of TAD research has been to establish what mechanisms drive TAD boundary formation, and how these processes are disrupted in diseases, including cancer.

\section{A Normal genomic organization}

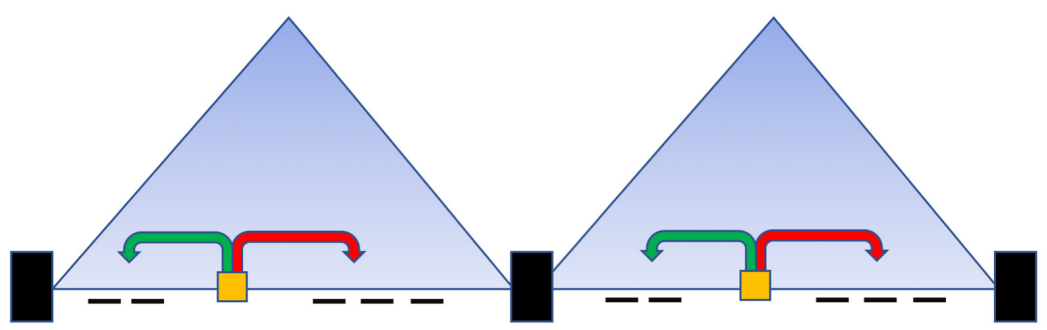

B Cancer genomic organization

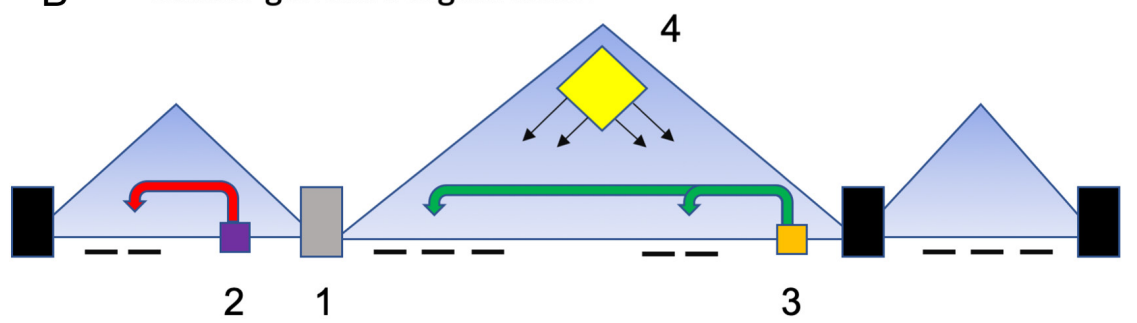

Figure 1

TAD organization in health and disease. (A) In normal cells TADs are organized such that boundaries arise by the action of multi-protein complexes centered on CTCF and cohesin complexes. These act to insulate the contents of the TAD which range in size from $100 \mathrm{~kb}$ to $1-2$ $\mathrm{mb}$. Within a TAD, enhancers (in orange) regulate target genes through further looping events and exert positive and negative impacts on gene expression. Often these gene expression patterns are highly coordinated and governed by multiple enhancer interactions. (B) In cancer cells there are many examples of these processes being corrupted. There is good evidence that boundary function is altered (1) with loss and gain of boundaries and changing the TAD structure. Generally, it appears the cancer genome gains more TADs of shorter length. This change of TAD structure can change enhancer function $(2,3)$ such that previously insulated genes are subsequently regulated by new enhancers. This is further distorted by structural variations impacting boundary function (1) and enhancer responses $(2,3)$. The coordinated gene regulation within a TAD also allows for emergent changes in epigenetic regulation (4). That is, mutations in epigenetic regulators such as EZH2 can modestly change the regulation of individual genes in a $T A D$, but the collective effect on all genes is pronounced if all the genes are on a pathway for example. 


\section{CCCTC-binding factor roles in TAD structure and genomic functions}

Principal amongst the proteins that organize TAD boundaries and therefore define TAD structure is the DNA-binding factor CCCTC-binding factor (CCTF), which contains 11 zinc finger motifs and binds across the genome. Human CTCF was cloned by Filippova and colleagues in 1996 by examining regulatory sequences proximal to the MYC gene and used these regions as bait to identify binding proteins (Filippova et al. 1996). This revealed the significant relationship between CTCF and MYC, in which CTCF is able to repress MYC expression. Analyses of the multiple CTCF zinc finger motifs that revealed differential binding abilities and suggested significant dexterity in binding and function (Filippova et al. 2002). Of course, this intimate relationship with MYC directly implicated CTCF in cancer development and catalyzed an intense arena of subsequent investigation.

Again, the $\beta$-globin gene locus offered further clues to the function of CTCF binding identified sites and supported the concept that CTCF could regulate gene expression, but also act to insulate and therefore control regulation (Bell et al. 1999). These discoveries suggested that these CTCF functions maybe common and conserved through vertebrates and necessary for precise gene regulation. Subsequently, chromatin conformation capture (3C) technologies applied to the histocompatibility complex genes also revealed the coordination and insulation roles that were dependent on CTCF (Majumder et al. 2008, Majumder \& Boss 2010). Chromatin immunoprecipitation and microarray approaches (ChIP-chip) initially demonstrated that at promoters, chromatin states and CTCF-binding sites were highly similar across cell types, whereas binding at enhancer regions was highly variable and correlated with cell type-specific gene expression (Heintzman et al. 2009, Smith et al. 2009).

These findings supported the concept that CTCF functions were in part dependent upon the genomic context of binding. Indeed, CTCF was shown to interact with numerous other proteins, and principal amongst these are members of the Cohesin complex (Wendt et al. 2008, Guo et al. 2012, Katainen et al. 2015). Cohesindependent TAD folding can bring distant enhancers into play with genes, and many known genomic-binding factors including the polycomb complex and YY1 all play a role in these functions (Donohoe et al. 2007). One process where CTCF has been extensively examined is during X inactivation (Donohoe et al. 2009), which has revealed that CTCF also interacts with noncoding lncRNA including TSIX and XIST to bring about silencing in part mediated by the repressor YY1. Indeed, YY1 heterozygote mice have altered TSIX and XIST expression which was pheno-copied by knockdown of CTCF (Pugacheva et al. 2005, Spencer et al. 2011, Yang et al. 2015). Similarly, FIRR lncRNA plays a role in X-chromosome inactivation and shown to be dependent on NCOR2 and SHARP binding (McHugh et al. 2015). CTCF also demonstrates very significant flexibility in terms of the interactions it undergoes with a wide array of other proteins (Ghirlando \& Felsenfeld 2016, Shin 2019). Furthermore, there are multiple CTCF isoforms ranging from 55 to $130 \mathrm{kD}$ and can modify each other's behavior (Li et al. 2019b), and furthermore, they are the target of a variety of posttranslational modifications ( et al. 2012b, Holwerda \& de Laat 2013, de Wit et al. 2015, Del Rosario et al. 2019). Analyses of CTCF genomic binding patters and chromatin organization have identified several patterns of looping (Handoko et al. 2011) including active and repressive loops that are functionally dependent upon size.

Together these findings support models of diverse interactions between CTCF and its isoforms, other repressors and IncRNA in a manner that is heavily influenced by genomic context. The complexity of these interactions, and their potential genomic impact, is heightened by the discoveries that the human genome contains approximately 30,000-40,000 CTCF-binding sites (Sanyal et al. 2012, Narendra et al. 2015). Therefore, CTCF is biologically impactful as a result of the frequency and diversity of its genomic interactions.

In parallel to studies in cell models, transgenic murine studies have been undertaken and have revealed that homozygous CTCF deletion is embryonically lethal, whereas heterozygotes are viable but poor breeders. In CTCF heterozygote animals there is clear evidence for changes in TAD structure that impact enhancer promoter interactions (Splinter et al. 2006, Kemp et al. 2014). For example, one of phenotypes in these mice is disruption of glucose homeostasis due to loss of insulation around the Pax6 locus (Tsui et al. 2012).

The boundary function of CTCF was conclusively demonstrated in 2015 by Narendra and colleagues by examining regulation on the HOX locus and established that CTCF insulates between regions of opposite HOX gene activity during development leading to activation of normally repressed members (Ing-Simmons et al. 2015, Narendra et al. 2015). In the context of this locus, CTCF insulates heterochromatin from euchromatin. More generally, it appears that TAD boundaries limit 
spread of activity across the genome, and in this way limit transcriptional noise from bidirectional enhancers. More recently, genome-editing approaches have allowed incremental removal of CTCF-binding sites associated with the well-established Sox9-Kcnj2 TAD on chr 11 of the murine genome. These approaches demonstrated consistent gene regulation, but subsequent gene inversions and repositioning of boundaries led to disease phenotypes suggesting that boundary erosion is required but not always sufficient for aberrant gene expression and phenotypic consequences (Despang et al. 2019). Therefore, the early proposition for TAD structure to limit the spread of repressive heterochromatin is probably not a universal function. Rather it now appears that the TAD structure constrains whatever is contained, be it active or repressive chromatin, and for aberrant transcriptional function other genomic distortion mechanisms may need to occur.

\section{Mechanisms of TAD boundary formation}

Although ChIP-Seq reveals that $~ 90 \%$ of TAD boundaries contain CTCF binding, there are many more CTCFbinding sites that are not contained within boundaries (Lobanenkov \& Zentner 2018, Zhang et al. 2018), and TAD boundary seems to be initiated and maintained by multiple proteins (Wang et al. 2012a, Marques et al. 2015, Huang et al. 2018). A caveat to this is that all these structures are identified in large bulk cell populations, and single-cell studies will need be applied (and technologies refined and developed) to address this issue accurately.

Although genetic and biochemical approaches have implicated different proteins in the formation of TAD boundaries, questions remain over how the protein complexes form, how are they guided, and how do they sustain boundary structure. Various models have been proposed to address this challenge including so-called 'handcuff' and 'extrusion' models (Dixon et al. 2016, Hansen et al. 2018, Racko et al. 2018). In the handcuff model CTCF and Cohesin have a common association, as is established with ChIA-Pet, which shows CTCF spanning TAD boundaries. That is, the Cohesin ring encircles chromatin fibers in a $30-40 \mathrm{~nm}$ ring and in this way, holds sister chromatids together.

Alternatively, a loop extrusion model has been proposed whereby DNA-binding complexes scan along DNA whilst also being tethered to an anchor CTCF site and do not close until it finds another CTCF motif in a convergent orientation. This process would explain why CTCF motif orientation at boundaries are convergent (de Wit et al. 2015) and that loss of one CTFC motif interacting and TAD bounds shift to next one and in this manner gives a degree of inherent stability. However, this model is also incomplete. For example, fundamentally, it remains unknown what protein complex is able to scan large genomic distances of 100s of kb in opposite directions and what happens to the supercoils that would be arise in the wake.

Most likely, there is contribution from all these forces with looping from enhancer to promoter that is stabilized by protein complexes and topological changes trigger activation. Loops can be further coordinated in transcription factor hubs, which has been appreciated for several years. Pre-looped topologies give hubs that provide liquid phase transitions (Strom et al. 2017) to promote stabilize the hub. In this manner, the enhancerpromoter interactions have a higher diffusion rate and faster transcriptional responses.

Finally, it is interesting to note that TAD boundaries are often enriched for highly active housekeeping genes, and the nucleosome spacing is shorter resulting in greater stiffness (Hug et al. 2017). It is possible that changing the flexibility can impact boundary and the affinity of CTCF and that these physical properties help to illuminate CTCF-independent boundaries.

\section{Disruption to TAD structure and CTCF in hormone-responsive cancers}

\section{Altered TAD structure and enhancer usage in hormone-responsive cancers}

Given these important relationships between genomic organization and coordinate gene regulation, it is not surprising that disruption to TAD structure is strongly implicated in a wide variety of diseases. One of the clearest and earliest identified examples was of the WNT6/IHH/EPHA4/PAX3 TAD on chr 2. Disruption and variation in boundary regions can result in the ectopic expression of these powerful developmental transcription factors in developing limb buds and leading to profound phenotypes in mice and humans (Lupianez et al. 2015, Koch 2016, Fabre et al. 2017, Wu et al. 2017, Cutrupi et al. 2018).

Similarly, epigenetic mechanisms can impact boundary formation. One of the earlier clues that de-regulated CTCF function was profoundly impactful was revealed through the altered DNA methylation at CTCF sites. Specifically, CpG methylation can impede CTCF binding and therefore remove insulator function (c) 2019 Society for Endocrinology Published by Bioscientifica Ltd. Printed in Great Britain 
as a driver of myotonic dystrophy (Filippova et al. 2001, Lopez Castel et al. 2011).

Altered CTCF status and function is strongly associated with cancer (Filippova et al. 2002, Splinter et al. 2006, Kemp et al. 2014). Murine modeling of its actions revealed that hemizygous deletion predisposes to cancer (Kemp et al. 2014). Indeed, CTCF deletion is associated with deregulated and increased levels of CpG methylation, and therefore, directly links changes in CTCF function to both genomic and epigenomic disruption. Given the wide diversity of genomic and epigenomic alterations that occur in cancer, it is not surprising that they can combine with mechanisms that control TAD boundary formation and can act as cancer drivers (Fig. 1B). Loss of the cohesin complex member, RAD21, leads to reduced intra-TAD chromatin interactions, and as a result increases TAD volume (Fudenberg et al. 2016, Poterlowicz et al. 2017, Rodriguez-Carballo et al. 2017). Targeted disruption of CTCF leads changes TAD sizes and is antagonized by cohesin changes (Barutcu et al. 2018, Luo et al. 2018, Sima et al. 2019).

There are strong examples of so-called 'enhancer hijacking' in which genomic disruptions to TAD boundaries allows previously insulated enhancers access to neighboring genes and changes in expression (Northcott et al. 2014, Ryan et al. 2015, Cuartero \& Merkenschlager 2018, Zimmerman et al. 2018, Haller et al. 2019, Martin-Garcia et al. 2019). This has been observed on chromosome 3 in AML where changes in CTCF expression weakens boundary and allows oncogenes to be regulated by nearby enhancers (Luo et al. 2018). Deletion of the CTCF motif at a boundary can shift the TAD structure and change gene regulation for example as has been shown for the HOX locus (Luo et al. 2018). Similar examples of such oncogenic hijacking of transcription factors is seen with NOTCH signaling in breast cancer (Petrovic et al. 2019), the nuclear receptor NR4A3 in acinic cell carcinomas (Haller et al. 2019) and in a similar manner, cyclin D highjacks enhancers from IgG locus in mantle cell lymphoma(Martin-Garcia et al. 2019). In other hijacking events a $\sim 1.8 \mathrm{Mb}$ TAD of chr 8 containing the MYC gene (Hyle et al. 2019) is extended to recruit enhancer regions that are themselves amplified in pediatric neuroblastoma (Zimmerman et al. 2018) by mechanisms that include insulator erosion. The net result is that enhancers associated with the lncRNA PVT1, downstream of MYC, are activated (Cho et al. 2018, Parolia et al. 2018, Ren et al. 2019). Pan-cancer approaches have identified altered regions containing enhancers that changed genes expression and provided integrative framework to begin to classify these events (Weischenfeldt et al. 2017).

TADs are enriched for specific histone modifications such as $\mathrm{H} 3 \mathrm{~K} 37 \mathrm{me} 3$, and mutations to EZH2 change its ability to govern this histone modification within a TAD. As a result, they occur more frequently than expected by chance, and therefore, a single mutation in an epigenetic regulatory protein can impact the regulation of multiple genes within a TAD. This has been demonstrated in lymphoma cells with wild-type or mutant EZH2, in EZH2 should normally target inactive TADs, and limit multiple genes to control differentiation but mutant EZH2 selectively target these genes and therefore disrupts this capacity (Donaldson-Collier et al. 2019).

Among hormone-responsive cancers there are examples of altered TAD regulation and structure. One of the most extensively studied is in the case of prostate cancer (PCa). In normal murine prostate development there is clear evidence that the developmental transcription factor, TBx18, is important for prostate development (Negi et al. 2019) and the use circularized chromosome conformation capture (4C) was used to find interacting regions that were stage and tissue specific in normal prostate development. In this manner, the authors were able to show enhancer interactions within a $1.5 \mathrm{Mb}$ TAD on chr 9 that controlled TBx18 and reveal how dynamically these interactions change during differentiation.

To identify aggressive PCa phenotypes investigators in the Cancer Genome Atlas (TCGA) (Cancer Genome Atlas Research Network 2013, 2015) consortium and other groups (Fraser et al. 2017) have applied integrative genomic approaches. These and earlier studies (Tomlins et al. 2005) identified common translocations between TMPRRS2 and ETS genes in PCa (Tomlins et al. 2005, Sanda et al. 2017). The TMPRSS 2 gene is androgen responsive, and its translocation leads to androgen-driven overexpression of the ETS transcription factor ERG, or other ETS family members, and acts as a cancer driver (Wang et al. 2011, 2014, Ulz et al. 2016). TMPRSS2:ERG fusions are being assessed as biomarkers (Tomlins et al. 2016) for precision medicine efforts that combine genomic information in algorithms to define disease state and predict treatment responses. This frequent translocation of ERG in prostate leads to significant changes in chromatin organization (Rickman et al. 2010, 2012).

Susan Clark and coworkers have focused on dissecting how this translocation and other events drive PCa. In the first instance they demonstrated changes in enhancer interactions as a result of the TMPRSS 2 translocation that
C 2019 Society for Endocrinology Published by Bioscientifica Ltd. Printed in Great Britain 
may re-wire cancer signaling and lead to dysregulation of gene expression programs (Taberlay et al. 2014). Subsequently they used the chromatin conformation capture technique Hi-C to capture all genomic-genomic interactions in prostate models (PrEC, LNCaP, PC-3) coupled with analyses of CTCF boundaries, and other genomic histone modification data. In this manner, they were able to develop a highly textured annotation of epigenomic context and TAD associations in nonmalignant and malignant cell models (Taberlay et al. 2016). This approach was able to demonstrate in PCa cell models that TAD boundaries were shifted, and new ones created, which overlapped with H3K4me3. That is, large TADs were divided into smaller TADs. As a result, 317 TADs were identified in PrEC whereas in the cancer cell models this increased to 622 (PC-3) and 1111 (LNCaP). Thus, it appears that larger TADs are normal and divided in cancer systems that most likely impact enhancer usage (Fig. 1B). There was also evidence that copy number variation impacts these structures. Finally, the anchor point associations of TADs correlated with changes in expression of adjacent genes, and remarkably these patterns of differential expression were identified both in cell lines and primary tumor data.

Other workers have begun to reveal the coordinated regulation of IncRNA and androgen receptor-regulated target genes were more likely within the same TAD, than different TADs (daSilva et al. 2018), again supporting the idea that TAD are organizational units in the cell.

In breast cancer, TAD mapping has been undertaken as part of analyses of RUNX1, and the impact of RUNX1 on TAD structure measured using Hi-C. Whilst RUNX1binding sites were enriched at TAD boundaries, there was no significant change in the boundary structure from knockdown of RUNCX1, which probably reflects the complex and stable nature of TAD boundaries. That is, they arise from many proteins interacting, but few of the protein alone can significantly change how they form (Barutcu et al. 2016).

\section{Changes to CTCF function in hormone-responsive cancers}

Across cancers, altered CTCF and its downstream consequences are much studied. Many workers in breast cancer have focused on mapping disease-associated enhancer access. For example, Luca Magnani and co-workers (Patten et al. 2018) have mapped enhancers from primary patient material and overlapped with GWAS-identified SNPs enriched in enhancers. They also demonstrated relationships between CTCF-dependent boundaries, enhancer strength and correlation with changes in mRNA suggesting that the interplay between boundaries, enhancer access and gene expression are all measurable in primary tumors. Another approach has been to delete CTCF-binding sites within proximity to estrogen receptor alpha $(\mathrm{ER} \alpha)$-regulated target genes using genome editing and identified that some, but not all, ER $\alpha$ enhancer-gene relationships are altered (Korkmaz et al. 2019). These studies reflects those of others also in breast cancer where CTCF was shown to insulate the ER $\alpha$ pioneer factor, FOXA1 (Zhang et al. 2010) and to repress oncogenic signals downstream of ERB2 (Brix et al. 2019).

Indeed many ERo-regulated genes associate with CTCF and can be captured in association with enhancer regions that loop to the lamina associated with gene suppression (Fiorito et al. 2016) and associate with periodic expression through the cell cycle, and disruptions to these relationships associate with worse patient outcome (Yamamoto et al. 2014, Dominguez et al. 2016). Together these findings suggest that CTCF actions are a significant regulator of ER $\alpha$ responses (Chan \& Song 2008) related to specific histology (Razavi et al. 2018) and overall outcomes.

In prostate cancer, CTCF sites associated with outcome identified by GWAS and CRISPR deletion of sites leads to increased gene expression of genes within loops and that FOXA1, AR and in same CTCF block (Taslim et al. 2012).

Workers have also examined how CTCF mutations and expression changes impacts the epigenome in ovarian cancer and established relationships to disease progression risks (Woloszynska-Read et al. 2011). Furthermore, the CTCF paralog, BORIS (Brother of the Regulator of Imprinted Sites) is altered in ovarian cancer and changes enhancer access and promotes invasive phenotypes (Hillman et al. 2019).

In pancreatic cancer a focus has been on the regulation of the PAX6 gene which is required for islet development, and it has been revealed that CTCF regulates the locus (Buckle et al. 2018), reflecting the phenotype of the CTCF heterozygote deletion in mice (Tsui et al. 2012). Pancreatic cancer has also been a cancer in which the interplay between CTCF and repression of MYC has been seen to be associated with progression and outcomes (Peng et al. 2019). Bioinformatic approaches have also been applied to integrate GWAS data with CTCF-binding sites and therefore identify a critical impact of a risk variant with altered boundary function and reduced expression of the putative anti-oncogene MFSD13A (Mei et al. 2019). (c) 2019 Society for Endocrinology Published by Bioscientifica Ltd. Printed in Great Britain 
In testes the CTCF/BORIS regulation of gene programs is expressed in primary spermatocytes but then silenced by DNA methylation. Reactivation in cancer cells is apparent making it a cancer testes antigen gene expression and a potential target for immunotherapy (MartinKleiner 2012). Reactivation of BORIS can bind hTERT and increase expression in ovarian and testicular cancers (Renaud et al. 2011). Finally, in the pituitary the human growth hormone cluster has been investigated and shown long-range genomic interactions (Tsai et al. 2014, 2016), but it remains to be established how important this is in pituitary cancer.

\section{A survey of CTCF and interacting components in hormone-responsive cancers}

To complement this review TCGA data from the adrenal, breast, kidney, ovarian, pancreatic, parathyroid, prostate, testis and thyroid cancer cohorts have been examined to reveal the mutation, copy number variation and expression of CTCF and genes for the various interacting proteins (Fig. 2). By mutational status, breast, ovarian and adrenocortical tumors cluster together driven by common mutations to cohesin complex (e.g. SMC3) and other chromosomal structural proteins (e.g. NCAPH2 and
REC8). The lncRNA HOTTIP is also frequently mutated in these tumors. By contrast, kidney, parathyroid and testicular cancers are essentially free from mutation in any of the genes examined. CTCF is not commonly mutated.

This is somewhat echoed by changes in copy number variation with $\mathrm{NCAPH} 2$ and SMC1B showing copy number loss in ovarian and adrenal cancer. CTCF has common loss in ovarian and breast cancer, but gain in adrenal cancer. However, there are other clear differences, with kidney cancer for example showing clear copy number loss for SMC3 but not mutation. Notable gains in copy number included RAD21 and STAG1 in ovarian and RAD21 also in adrenal, testicular and breast cancers. STAG3 is also amplified in adrenal, kidney and testicular cancers. Similarly, STAG1 has loss of copy number variation and reduced expression uniquely in pheochromocytoma. These findings reflect an emerging appreciation of the role of STAG family members across cancers (Cheng et al. 2015, Mondal et al. 2019, Romero-Perez et al. 2019). Whilst not mutated in any of the cancer NCOR2 is highly amplified in adrenal cancer, as are HOTTIP, NCAPG2 and EZH2, which are all mutated in the same cancer. Expression changes also distinguish ovarian cancer with reduced expression of CTCF, NCAPH2 and upregulation of SMC4. These patterns are somewhat echoed by breast and
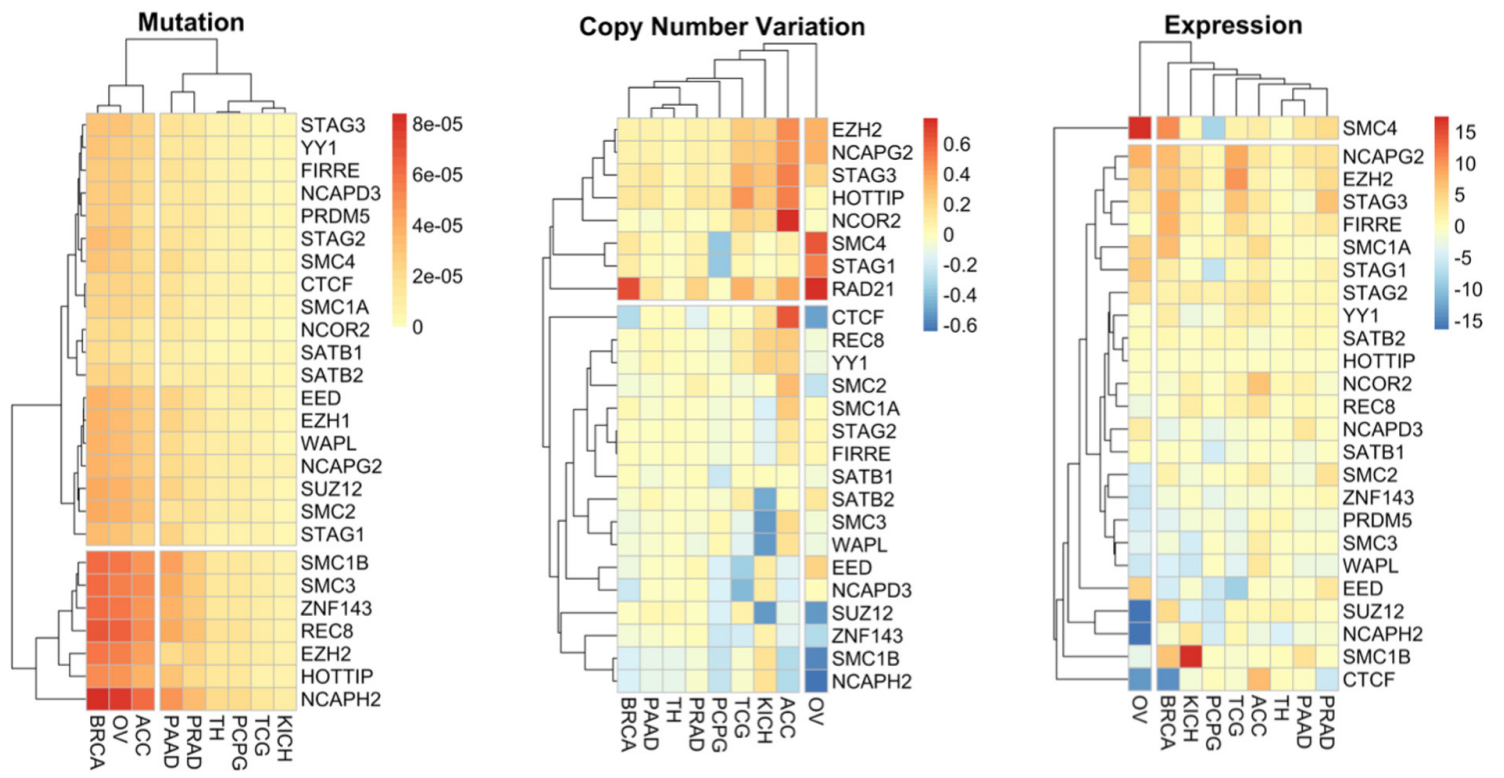

Figure 2

Mutation, copy number variation and expression of genes involved in boundary formation in hormone responsive cancers. Gene mutation, copy number variation and expression z-score pan-cancer data for breast (BRCA), ovarian (OV), pancreatic (PAAD), prostate (PRAD), thyroid (TH), pheochromocytoma (PCPG), testicular germ cell (TCG), adrenocortical cancers(ACC) were downloaded using the R platform for statistical computing using the cgdsr package. The genes selected were chosen by the studies highlighted in the text, as well as choosing paralogs identified by Human Genome Nomenclature. Gene mutation and copy number variation data was normalized to the number of tumors within the cohort, and also normalized to gene length for the mutation data. The normalized mutation, copy number variation and expression were then visualized as a heatmap (pheatmap) using average Manhattan clustering. 
kidney cancers. The amplification of NCOR2 in adrenal cancer is reflected by modest upregulation of the mRNA. Similarly, SMC1B has a modest gain of copy number in kidney cancer but strong mRNA upregulation.

\section{Statistical and computational challenges in the analyses of TADs}

Statistical and computational frameworks were essential for the capture, analyses and interpretation of chromatin conformation data, and the development of these frameworks finally enabled the genome wide analyses in Hi-C data (2012) (Dixon et al. 2012, Nora et al. 2012). These approaches apply complex genomic analyses and there are several areas where variance can impact the data interpretation, from wet-lab experimental parameters to dry-lab analyses. An ongoing challenge is to harmonize these techniques and analytical pipelines. These include cross-linking parameters, choice of restriction enzymes and library preparation. Similarly, the statistical approaches differ in their assumptions, for example how to model the distribution of the data, how to consider the impact of distance between events, and how best to determine differential TAD events (Mora et al. 2016, Stansfield et al. 2019).

There are multiple algorithms to identify TADs. For example, Dali and Blanchette (Dali \& Blanchette 2017) recently compared seven algorithms. Interestingly, the requirements of RAM to run algorithms whilst significant ( $20 \mathrm{~Gb})$, depending on the resolution for example, $100 \mathrm{~kb}$ compared to $25 \mathrm{~kb}$, is now such that once the raw read data are aligned, the analyses can be undertaken on most desktop computers. Perhaps, the optimal resolution to consider TAD analyses is around $50 \mathrm{~kb}$ and requires 500 million reads. Naturally, with higher resolution, more TADs are predicted and the mean size decreases. Among most of the commonly used algorithms there $\sim 75 \%$ sites convergence predicted in at least two tools e.g. with HiCSeg (Levy-Leduc et al. 2014), TopDom (Shin et al. 2016). Tools probably are very conservative and underestimate by missing $25 \%$ of manually annotated TADs (Stansfield et al. 2019) (Table 1).

Of course, a challenge for the field in both wet-lab design and dry-lab analyses is that the work to-date is from bulk culture and there is a need to undertake single cell or purified cell populations to ensure that TAD structure is not an emergent property from cell population averaging. Recently, this issue has been addressed by complementary approaches in single cells using partition $\sim 30 \mathrm{~kb}$ across a region of chromosome 21 . Interestingly, this revealed TAD structure and associations with CTCF and cohesin preference; cohesin depletion did not impact structure at single cell suggesting its CTCF-cohesion that is important (Bintu et al. 2018). In parallel, others are optimizing singlecell approaches that combine $\mathrm{Hi}-\mathrm{C}$ and imaging and suggest that there are areas of significant heterogeneity between cells in terms of genomic and allele-specific organization (Finn et al. 2019).

However, perhaps, the greatest challenge will be the data integration approaches, which will be designed, implemented and interpreted by bioinformatically trained researchers. We now stand approximately 50 years after the conception of bioinformatics (reviewed in Hogeweg 2011) and, in comparison to the 50-year widespread application of molecular biology (Weaver 1970, Danna \& Nathans 1971,

Table 1 Representative computational packages for analyses of chromatin capture experiments. Each package is implemented in the R language for statistical computing and the focus of the data type and function of the analytical approach alongside the relevant publications are indicated.

\begin{tabular}{ll}
\hline Package & Focus \\
\cline { 1 - 1 } sevenC & CTCF ChIP-Seq \\
diffloop & ChIA-PET and RNA-Seq \\
R3Cseq & $3 \mathrm{C}$ \\
CHiCAGO & Capture-Hi-C \\
HiTC & Hi-C \\
multiHiCcompare & Hi-C \\
HiCRep HiCseg & Hi-C \\
TopDom & Hi-C \\
\hline
\end{tabular}

Function

Publication

Predicts chromatin loops from CTCF ChIP-Seq data

Identify differential chromatin topology between cell conditions and annotate with gene expression Identify genomic loops between two fixed points Analyses of $\mathrm{HiC}$ data that are enriched for genomic features of interest Normalization and visualization of Hi-C data, TAD detection Zhang et al. 2010 Normalization and visualization of $\mathrm{Hi}-\mathrm{C}$ data, TAD detection Tomlins et al. 2005

Assess reproducibility in $\mathrm{Hi}-\mathrm{C}$ data, and normalization and Zimmerman et al. 2018 visualization of Hi-C data, TAD detection

Normalization and visualization of Hi-C data, TAD detection Ulz et al. 2016 
Saiki et al. 1988, Hunkapiller et al. 1991), it is far from clear that bioinformatics is on a trajectory to also become democratized. Currently, it is far from clear how the research community stands in terms of the widespread application of bioinformatics. The unprecedented insight generated by the large-scale biological meta-projects such as The Human Genome Project (Roberts et al. 2001), ENCODE (ENCODE Consortium Project 2007, Birney 2012), RoadMap Epigenome (Roadmap Epigenomics Consortium 2015), FANTOM (Sanli et al. 2013), IHEC (Bujold et al. 2016, Chen et al. 2016) and TCGA (Cancer Genome Atlas Research Network 2013) was achieved in large part through the success of the intensive data analytic initiatives within these projects. Unfortunately, at present, there is a worrying possibility that, given the everincreasing computational and statistical requirements to map genomic topology, these remarkable achievements will themselves become islands of bioinformatically driven genomic insight in oceans of reductionist biology. This will profoundly impede dissection and exploitation of how TAD structure governs hormonal signaling and is corrupted in cancer.

\section{Summary and future challenges}

The visual density of the nucleus impeded early workers from appreciating the diversity of the structure-function relationships that were dynamically regulated across the life-cycle of the cell. Advancements in microscopy and the development of molecular biology techniques enabled significant developments in understanding, but the major catalyst for deciphering genomic organization and function was sequencing the human genome, and the development of statistical approaches and computational resources to undertake complex genomic analyses. This led to the first attempts to capture the 3D genome in 2012 and the identification of TADs (Dixon et al. 2012, Nora et al. 2012). Subsequently, it has become clear that the TAD structure is both biologically important and provides a major conceptual level for understanding genomic organization and gene regulation.

In terms of understanding how TAD structure can impact hormone-responsive cancers, there are both opportunities and challenges. The opportunity exists to integrate the understanding of TAD structure and organization into a comprehensive understanding of cancer and progression risks. For example, the choices of genomic bindings sites (cistrome) for either the $\mathrm{ER} \alpha$ in breast cancer or the AR in prostate cancer are highly diverse. Understanding is emerging of the forces that shape these cistromes and how they determine the magnitude and amplitude of transcriptional signals (transcriptome), but many questions remain. It is unclear how TAD structure truly determines these cistrometranscriptome relationships, and which mechanisms distort these actions in cancer progression and therapy resistance. There are clear examples of TAD boundary erosion and enhancer hijacking, but it is largely unknown at the genome-wide level how germline variation, somatic structural variation and epigenomic mechanisms may each contribute to these processes of boundary erosion and determining enhancer promiscuity.

In many ways, this is a readily achievable research goal at least within cell models; 3D genomic approaches are well developed as are cistromic and transcriptomic methodologies. However, this now raises the prospect that hormone responsive cancer research will require 3D-cistrome-transcriptome data capture and analyses. Collectively, this is neither a trivial experimental challenge nor a financially modest endeavor. However, significant efforts have been made by leaders in the field to generate 3D genome browsers that will potentially enable more rapid assimilation of this information to the wider research community (Robinson et al. 2018, Wang et al. 2018, Yauy et al. 2018, Li et al. 2019a, Morita et al. 2019).

Transition into patient samples is always more challenging, but there is a realistic possibility that greater understanding in the basic biology of TAD structure and function and how germline variation, somatic structural variation and epigenomic mechanisms converge selectively on specific TAD will lead to a personalized prediction of individual risk of disease and progression. For example, analyses of peripheral blood cells will reveal germline interplay with TAD boundary structure, and analyses of circulating tumor cells will similarly reveal how these boundaries are distorted. Computational approaches can impute or predict TAD structure and intra-TAD configuration (Sauerwald et al. 2017, Matthews \& Waxman 2018).

In turn, mathematical modeling of these approaches within a systems biology framework will allow predictive modeling of hormonal responsiveness, perhaps in the first instance for key cancer pre-disposing TADs such as the one on chr 8 containing MYC. It is highly likely that analyses of how germline variation, somatic structural variation and epigenomic mechanisms impacts TAD structure and in turn governs hormone signaling and will be essential to develop a more complete understanding https://erc bioscientifica com https://doi.org/10.1530/ERC-19-0348 (c) 2019 Society for Endocrinology Published by Bioscientifica Ltd. Printed in Great Britain 
of how hormone responsive cancers arise in humans, propagate and respond to therapies.

\section{Declaration of interest}

The author declares that there is no conflict of interest that could be perceived as prejudicing the impartiality of this review.

\section{Funding}

This work was funded by the Prostate program of the Department of Defense Congressionally Directed Medical Research Programs [W81XWH-14-1-0608] and from the National Cancer Institute (NCI) grant awarded to the OSUCCC The James, CCSG P30CA016058

\section{References}

Arceci RJ \& Gross PR 1980 Histone gene expression: progeny of isolated early blastomeres in culture make the same change as in the embryo. Science 209 607-609. (https://doi.org/10.1126/ science.7394523)

Barutcu AR, Hong D, Lajoie BR, McCord RP, van Wijnen AJ, Lian JB, Stein JL, Dekker J, Imbalzano AN \& Stein GS 2016 RUNX1 contributes to higher-order chromatin organization and gene regulation in breast cancer cells. Biochimica \& Biophysica Acta 1859 1389-1397. (https://doi.org/10.1016/j.bbagrm.2016.08.003)

Barutcu AR, Maass PG, Lewandowski JP, Weiner CL \& Rinn JL 2018 A TAD boundary is preserved upon deletion of the CTCF-rich Firre locus. Nature Communications 9 1444. (https://doi.org/10.1038/ s41467-018-03614-0)

Bell AC, West AG \& Felsenfeld G 1999 The protein CTCF is required for the enhancer blocking activity of vertebrate insulators. Cell $\mathbf{9 8}$ 387-396. (https://doi.org/10.1016/s0092-8674(00)81967-4)

Bintu B, Mateo LJ, Su JH, Sinnott-Armstrong NA, Parker M, Kinrot S, Yamaya K, Boettiger AN \& Zhuang X 2018 Super-resolution chromatin tracing reveals domains and cooperative interactions in single cells. Science 362 eaau1783. (https://doi.org/10.1126/science.aau1783)

Birney E 2012 The making of ENCODE: lessons for big-data projects. Nature 489 49-51. (https://doi.org/10.1038/489049a)

Blom van Assendelft G, Hanscombe O, Grosveld F \& Greaves DR 1989 The beta-globin dominant control region activates homologous and heterologous promoters in a tissue-specific manner. Cell 56 969-977. (https://doi.org/10.1016/0092-8674(89)90630-2)

Brix DM, Tvingsholm SA, Hansen MB, Clemmensen KB, Ohman T, Siino V, Lambrughi M, Hansen K, Puustinen P, Gromova I, et al. 2019 Release of transcriptional repression via ErbB2-induced, SUMOdirected phosphorylation of myeloid zinc finger- 1 serine 27 activates lysosome redistribution and invasion. Oncogene 38 3170-3184. (https://doi.org/10.1038/s41388-018-0653-x)

Buckle A, Nozawa RS, Kleinjan DA \& Gilbert N 2018 Functional characteristics of novel pancreatic Pax6 regulatory elements. Human Molecular Genetics 27 3434-3448. (https://doi.org/10.1093/hmg/ ddy255)

Bujold D, Morais DAL, Gauthier C, Côté C, Caron M, Kwan T, Chen KC, Laperle J, Markovits AN, Pastinen T, et al. 2016 The International Human Epigenome Consortium Data portal. Cell Systems 3 496-499. e2. (https://doi.org/10.1016/j.cels.2016.10.019)

Cancer Genome Atlas Research Network 2015 The molecular taxonomy of primary prostate cancer. Cell 163 1011-1025. (https://doi. org/10.1016/j.cell.2015.10.025)
Cancer Genome Atlas Research Network, Weinstein JN, Collisson EA, Mills GB, Shaw KR, Ozenberger BA, Ellrott K, Shmulevich I, Sander C, Stuart JM, et al. 2013 The Cancer Genome Atlas PanCancer analysis project. Nature Genetics 45 1113-1120. (https://doi. org/10.1038/ng.2764)

Carter D, Chakalova L, Osborne CS, Dai YF \& Fraser P 2002 Long-range chromatin regulatory interactions in vivo. Nature Genetics $\mathbf{3 2}$ 623-626. (https://doi.org/10.1038/ng1051)

Chan CS \& Song JS 2008 CCCTC-binding factor confines the distal action of estrogen receptor. Cancer Research 68 9041-9049. (https:// doi.org/10.1158/0008-5472.CAN-08-2632)

Chang P, Gohain M, Yen MR \& Chen PY 2018 Computational methods for assessing chromatin hierarchy. Computational \& Structural Biotechnology Journal 16 43-53. (https://doi.org/10.1016/j.csbj.2018.02.003)

Chen L, Ge B, Casale FP, Vasquez L, Kwan T, Garrido-Martín D, Watt S, Yan Y, Kundu K, Ecker S, et al. 2016 Genetic drivers of epigenetic and transcriptional variation in human immune cells. Cell 167 1398-1414.e24. (https://doi.org/10.1016/j.cell.2016.10.026)

Cheng F, Liu C, Lin CC, Zhao J, Jia P, Li WH \& Zhao Z 2015 A gene gravity model for the evolution of cancer genomes: a study of 3,000 cancer genomes across 9 cancer types. PLOS Computational Biology 11 e1004497. (https://doi.org/10.1371/journal.pcbi.1004497)

Chenoweth AM, Trist HM, Tan PS, Wines BD \& Hogarth PM 2015 The high-affinity receptor for IgG, FcgammaRI, of humans and nonhuman primates. Immunological Reviews 268 175-191. (https://doi. org/10.1111/imr.12366)

Cho SW, Xu J, Sun R, Mumbach MR, Carter AC, Chen YG, Yost KE, Kim J, He J, Nevins SA, et al. 2018 Promoter of lncRNA gene PVT1 is a tumor-suppressor DNA boundary element. Cell 173 1398-1412. e22. (https://doi.org/10.1016/j.cell.2018.03.068)

Cuartero S \& Merkenschlager M 2018 Three-dimensional genome organization in normal and malignant haematopoiesis. Current Opinion in Hematology 25 323-328. (https://doi.org/10.1097/ MOH.0000000000000436)

Cutrupi AN, Brewer MH, Nicholson GA \& Kennerson ML 2018 Structural variations causing inherited peripheral neuropathies: a paradigm for understanding genomic organization, chromatin interactions, and gene dysregulation. Molecular Genetics \& Genomic Medicine 6 422-433. (https://doi.org/10.1002/mgg3.390)

Dali R \& Blanchette M 2017 A critical assessment of topologically associating domain prediction tools. Nucleic Acids Research $\mathbf{4 5}$ 2994-3005. (https://doi.org/10.1093/nar/gkx145)

Danna K \& Nathans D 1971 Specific cleavage of simian virus 40 DNA by restriction endonuclease of Hemophilus influenzae. PNAS $6 \mathbf{8}$ 2913-2917. (https://doi.org/10.1073/pnas.68.12.2913)

daSilva LF, Beckedorff FC, Ayupe AC, Amaral MS, Mesel V, Videira A, Reis EM, Setubal JC \& Verjovski-Almeida S 2018 Chromatin landscape distinguishes the genomic loci of hundreds of androgen-receptorassociated LincRNAs from the loci of non-associated LincRNAs. Frontiers in Genetics 9 132. (https://doi.org/10.3389/fgene.2018.00132)

de Laat W \& Duboule D 2013 Topology of mammalian developmental enhancers and their regulatory landscapes. Nature 502 499-506. (https://doi.org/10.1038/nature12753)

de Wit E, Vos ES, Holwerda SJ, Valdes-Quezada C, Verstegen MJ, Teunissen H, Splinter E, Wijchers PJ, Krijger PH \& de Laat W 2015 CTCF binding polarity determines chromatin looping. Molecular Cell 60 676-684. (https://doi.org/10.1016/j.molcel.2015.09.023)

Del Rosario BC, Kriz AJ, Del Rosario AM, Anselmo A, Fry CJ, White FM, Sadreyev RI \& Lee JT 2019 Exploration of CTCF post-translation modifications uncovers Serine-224 phosphorylation by PLK1 at pericentric regions during the G2/M transition. eLife $\mathbf{8}$ e42341. (https://doi.org/10.7554/eLife.42341)

Denker A \& de Laat W 2016 The second decade of 3C technologies: detailed insights into nuclear organization. Genes \& Development 30 1357-1382. (https://doi.org/10.1101/gad.281964.116) (c) 2019 Society for Endocrinology Published by Bioscientifica Ltd. Printed in Great Britain 
Despang A, Schöpflin R, Franke M, Ali S, Jerković I, Paliou C, Chan WL, Timmermann B, Wittler L, Vingron M, et al. 2019 Functional dissection of the Sox9-Kcnj2 locus identifies nonessential and instructive roles of TAD architecture. Nature Genetics 51 1263-1271. (https://doi.org/10.1038/s41588-019-0466-z)

Dillon N, Trimborn T, Strouboulis J, Fraser P \& Grosveld F 1997 The effect of distance on long-range chromatin interactions. Molecular Cell 1 131-139. (https://doi.org/10.1016/S1097-2765(00)80014-3)

Dixon JR, Selvaraj S, Yue F, Kim A, Li Y, Shen Y, Hu M, Liu JS \& Ren B 2012 Topological domains in mammalian genomes identified by analysis of chromatin interactions. Nature $\mathbf{4 8 5} 376-380$. (https://doi. org/10.1038/nature11082)

Dixon JR, Gorkin DU \& Ren B 2016 Chromatin domains: the unit of chromosome organization. Molecular Cell 62 668-680. (https://doi. org/10.1016/j.molcel.2016.05.018)

Dominguez D, Tsai YH, Gomez N, Jha DK, Davis I \& Wang Z 2016 A high-resolution transcriptome map of cell cycle reveals novel connections between periodic genes and cancer. Cell Research $\mathbf{2 6}$ 946-962. (https://doi.org/10.1038/cr.2016.84)

Donaldson-Collier MC, Sungalee S, Zufferey M, Tavernari D, Katanayeva N, Battistello E, Mina M, Douglass KM, Rey T, Raynaud F, et al. 2019 EZH2 oncogenic mutations drive epigenetic, transcriptional, and structural changes within chromatin domains. Nature Genetics 51 517-528. (https://doi.org/10.1038/s41588-0180338-y)

Donohoe ME, Zhang LF, Xu N, Shi Y \& Lee JT 2007 Identification of a Ctcf cofactor, Yy1, for the X chromosome binary switch. Molecular Cell 25 43-56. (https://doi.org/10.1016/j.molcel.2006.11.017)

Donohoe ME, Silva SS, Pinter SF, Xu N \& Lee JT 2009 The pluripotency factor Oct4 interacts with Ctcf and also controls X-chromosome pairing and counting. Nature $\mathbf{4 6 0}$ 128-132. (https://doi.org/10.1038/ nature08098)

ENCODE Consortium Project, Birney E, Stamatoyannopoulos JA, Dutta A, Guigó R, Gingeras TR, Margulies EH, Weng Z, Snyder M, Dermitzakis ET, et al. 2007 Identification and analysis of functional elements in $1 \%$ of the human genome by the ENCODE pilot project. Nature 447 799-816. (https://doi.org/10.1038/nature05874)

Fabre PJ, Leleu M, Mormann BH, Lopez-Delisle L, Noordermeer D, Beccari L \& Duboule D 2017 Large scale genomic reorganization of topological domains at the HoxD locus. Genome Biology 18149. (https://doi.org/10.1186/s13059-017-1278-z)

Filippova GN, Fagerlie S, Klenova EM, Myers C, Dehner Y, Goodwin G, Neiman PE, Collins SJ \& Lobanenkov VV 1996 An exceptionally conserved transcriptional repressor, CTCF, employs different combinations of zinc fingers to bind diverged promoter sequences of avian and mammalian c-myc oncogenes. Molecular \& Cellular Biology 16 2802-2813. (https://doi.org/10.1128/mcb.16.6.2802)

Filippova GN, Thienes CP, Penn BH, Cho DH, Hu YJ, Moore JM, Klesert TR, Lobanenkov VV \& Tapscott SJ 2001 CTCF-binding sites flank CTG/CAG repeats and form a methylation-sensitive insulator at the DM1 locus. Nature Genetics 28 335-343. (https://doi. org/10.1038/ng570)

Filippova GN, Qi CF, Ulmer JE, Moore JM, Ward MD, Hu YJ, Loukinov DI, Pugacheva EM, Klenova EM, Grundy PE, et al. 2002 Tumor-associated zinc finger mutations in the CTCF transcription factor selectively alter tts DNA-binding specificity. Cancer Research 62 $48-52$.

Finn EH, Pegoraro G, Brandao HB, Valton AL, Oomen ME, Dekker J, Mirny L \& Misteli T 2019 Extensive heterogeneity and intrinsic variation in spatial genome organization. Cell 176 1502-1515.e10. (https://doi.org/10.1016/j.cell.2019.01.020)

Fiorito E, Sharma Y, Gilfillan S, Wang S, Singh SK, Satheesh SV, Katika MR, Urbanucci A, Thiede B, Mills IG, et al. 2016 CTCF modulates estrogen receptor function through specific chromatin and nuclear matrix interactions. Nucleic Acids Research $\mathbf{4 4}$ 10588-10602. (https://doi.org/10.1093/nar/gkw785)
Franke WW 1988 Matthias Jacob Schleiden and the definition of the cell nucleus. European Journal of Cell Biology 47 145-156.

Fraser M, Sabelnykova VY, Yamaguchi TN, Heisler LE, Livingstone J, Huang V, Shiah YJ, Yousif F, Lin X, Masella AP, et al. 2017 Genomic hallmarks of localized, non-indolent prostate cancer. Nature $\mathbf{5 4 1}$ 359-364. (https://doi.org/10.1038/nature20788)

Fu S, Zhang L, Lv J, Zhu B, Wang W \& Wang X 2019 Two main stream methods analysis and visual 3D genome architecture. Seminars in Cell \& Developmental Biology 90 43-53. (https://doi.org/10.1016/j. semcdb.2018.07.011)

Fudenberg G, Imakaev M, Lu C, Goloborodko A, Abdennur N \& Mirny LA 2016 Formation of chromosomal domains by loop extrusion. Cell Reports 15 2038-2049. (https://doi.org/10.1016/j. celrep.2016.04.085)

Furlong EEM \& Levine M 2018 Developmental enhancers and chromosome topology. Science 361 1341-1345. (https://doi. org/10.1126/science.aau0320)

Ghirlando R \& Felsenfeld G 2016 CTCF: making the right connections. Genes \& Development 30 881-891. (https://doi.org/10.1101/ $\operatorname{gad} .277863 .116)$

Gibcus JH \& Dekker J 2013 The hierarchy of the 3D genome. Molecular Cell 49 773-782. (https://doi.org/10.1016/j.molcel.2013.02.011)

Gilad Y \& Lancet D 2003 Population differences in the human functional olfactory repertoire. Molecular Biology and Evolution 20 307-314. (https://doi.org/10.1093/molbev/msg013)

Gong Y, Lazaris C, Sakellaropoulos T, Lozano A, Kambadur P, Ntziachristos P, Aifantis I \& Tsirigos A 2018 Stratification of TAD boundaries reveals preferential insulation of super-enhancers by strong boundaries. Nature Communications 9 542. (https://doi. org/10.1038/s41467-018-03017-1)

Guo Y, Monahan K, Wu H, Gertz J, Varley KE, Li W, Myers RM, Maniatis T \& Wu Q 2012 CTCF/cohesin-mediated DNA looping is required for protocadherin alpha promoter choice. PNAS 109 21081-21086. (https://doi.org/10.1073/pnas.1219280110)

Haller F, Bieg M, Will R, Körner C, Weichenhan D, Bott A, Ishaque N, Lutsik P, Moskalev EA, Mueller SK, et al. 2019 Enhancer hijacking activates oncogenic transcription factor NR4A3 in acinic cell carcinomas of the salivary glands. Nature Communications 10368. (https://doi.org/10.1038/s41467-018-08069-x)

Handoko L, Xu H, Li G, Ngan CY, Chew E, Schnapp M, Lee CW, Ye C, Ping JL, Mulawadi F, et al. 2011 CTCF-mediated functional chromatin interactome in pluripotent cells. Nature Genetics $\mathbf{4 3}$ 630-638. (https://doi.org/10.1038/ng.857)

Hanscombe O, Whyatt D, Fraser P, Yannoutsos N, Greaves D, Dillon N \& Grosveld F 1991 Importance of globin gene order for correct developmental expression. Genes \& Development 5 1387-1394. (https://doi.org/10.1101/gad.5.8.1387)

Hansen AS, Cattoglio C, Darzacq X \& Tjian R 2018 Recent evidence that TADs and chromatin loops are dynamic structures. Nucleus 9 20-32. (https://doi.org/10.1080/19491034.2017.1389365)

Harmston N, Ing-Simmons E, Tan G, Perry M, Merkenschlager M \& Lenhard B 2017 Topologically associating domains are ancient features that coincide with Metazoan clusters of extreme noncoding conservation. Nature Communications 8 441. (https://doi.org/10.1038/ s41467-017-00524-5)

Heijnen IA \& van de Winkel JG 1997 Human IgG Fc receptors. International Reviews of Immunology 16 29-55. (https://doi. org/10.3109/08830189709045702)

Heintzman ND, Hon GC, Hawkins RD, Kheradpour P, Stark A, Harp LF, Ye Z, Lee LK, Stuart RK, Ching CW, et al. 2009 Histone modifications at human enhancers reflect global cell-type-specific gene expression. Nature 459 108-112. (https://doi.org/10.1038/nature07829)

Hillman JC, Pugacheva EM, Barger CJ, Sribenja S, Rosario S, Albahrani M, Truskinovsky AM, Stablewski A, Liu S, Loukinov DI, et al. 2019 BORIS expression in ovarian cancer precursor cells alters the CTCF cistrome and enhances invasiveness through GALNT14. https://erc.bioscientifica.com

https://doi.org/10.1530/ERC-19-0348 (c) 2019 Society for Endocrinology Published by Bioscientifica Ltd. Printed in Great Britain 
Molecular Cancer Research [epub]. (https://doi.org/10.1158/1541-7786. MCR-19-0310)

Hogeweg P 2011 The roots of bioinformatics in theoretical biology. PLOS Computational Biology 7 e1002021. (https://doi.org/10.1371/journal. pcbi.1002021)

Holwerda SJ \& de Laat W 2013 CTCF: the protein, the binding partners, the binding sites and their chromatin loops. Philosophical Transactions of the Royal Society of London. Series B, Biological Sciences 368 20120369. (https://doi.org/10.1098/rstb.2012.0369)

Huang J, Li K, Cai W, Liu X, Zhang Y, Orkin SH, Xu J \& Yuan GC 2018 Dissecting super-enhancer hierarchy based on chromatin interactions. Nature Communications 9 943. (https://doi.org/10.1038/ s41467-018-03279-9)

Hug CB, Grimaldi AG, Kruse K \& Vaquerizas JM 2017 Chromatin architecture emerges during zygotic genome activation independent of transcription. Cell 169 216-228.e19. (https://doi.org/10.1016/j. cell.2017.03.024)

Hunkapiller T, Kaiser RJ, Koop BF \& Hood L 1991 Large-scale and automated DNA sequence determination. Science 254 59-67. (https://doi.org/10.1126/science.1925562)

Hyle J, Zhang Y, Wright S, Xu B, Shao Y, Easton J, Tian L, Feng R, Xu P \& Li C 2019 Acute depletion of CTCF directly affects MYC regulation through loss of enhancer-promoter looping. Nucleic Acids Research 47 6699-6713. (https://doi.org/10.1093/nar/gkz462)

Ing-Simmons E, Seitan VC, Faure AJ, Flicek P, Carroll T, Dekker J, Fisher AG, Lenhard B \& Merkenschlager M 2015 Spatial enhancer clustering and regulation of enhancer-proximal genes by cohesin. Genome Research 25 504-513. (https://doi.org/10.1101/gr.184986.114)

Jiang Y, Loh YE, Rajarajan P, Hirayama T, Liao W, Kassim BS, Javidfar B, Hartley BJ, Kleofas L, Park RB, et al. 2017 The methyltransferase SETDB1 regulates a large neuron-specific topological chromatin domain. Nature Genetics 49 1239-1250. (https://doi.org/10.1038/ng.3906)

Katainen R, Dave K, Pitkänen E, Palin K, Kivioja T, Välimäki N, Gylfe AE, Ristolainen H, Hänninen UA, Cajuso T, et al. 2015 CTCF/ cohesin-binding sites are frequently mutated in cancer. Nature Genetics 47 818-821. (https://doi.org/10.1038/ng.3335)

Kemp CJ, Moore JM, Moser R, Bernard B, Teater M, Smith LE, Rabaia NA, Gurley KE, Guinney J, Busch SE, et al. 2014 CTCF haploinsufficiency destabilizes DNA methylation and predisposes to cancer. Cell Reports 7 1020-1029. (https://doi.org/10.1016/j. celrep.2014.04.004)

Koch L 2016 Chromatin: going a TAD out on a limb. Nature Reviews. Genetics 17 717. (https://doi.org/10.1038/nrg.2016.140)

Kojima MK 1960 Acceleration of the cleavage of sea urchin eggs by vital staining with neutral red. Experimental Cell Research 20 565-573. (https://doi.org/10.1016/0014-4827(60)90124-5)

Korkmaz G, Manber Z, Lopes R, Prekovic S, Schuurman K, Kim Y, Teunissen H, Flach K, de Wit E, Galli GG, et al. 2019 A CRISPR-Cas9 screen identifies essential CTCF anchor sites for estrogen receptordriven breast cancer cell proliferation. Nucleic Acids Research (https:// doi.org/10.1093/nar/gkz675)

Krefting J, Andrade-Navarro MA \& Ibn-Salem J 2018 Evolutionary stability of topologically associating domains is associated with conserved gene regulation. BMC Biology 16 87. (https://doi. org/10.1186/s12915-018-0556-x)

Krumm A \& Duan Z 2019 Understanding the 3D genome: emerging impacts on human disease. Seminars in Cell \& Developmental Biology 90 62-77. (https://doi.org/10.1016/j.semcdb.2018.07.004)

Levy-Leduc C, Delattre M, Mary-Huard T \& Robin S 2014 Twodimensional segmentation for analyzing Hi-C data. Bioinformatics 30 i386-i392. (https://doi.org/10.1093/bioinformatics/btu443)

Li D, Hsu S, Purushotham D, Sears RL \& Wang T 2019a WashU epigenome browser update 2019. Nucleic Acids Research 47 W158-W165. (https://doi.org/10.1093/nar/gkz348)

Li J, Huang K, Hu G, Babarinde IA, Li Y, Dong X, Chen YS, Shang L, Guo W, Wang J, et al. 2019b An alternative CTCF isoform antagonizes canonical CTCF occupancy and changes chromatin architecture to promote apoptosis. Nature Communications 101535. (https://doi.org/10.1038/s41467-019-08949-w)

Lobanenkov VV \& Zentner GE 2018 Discovering a binary CTCF code with a little help from BORIS. Nucleus 9 33-41. (https://doi.org/10.10 80/19491034.2017.1394536)

Lopez Castel A, Nakamori M, Tome S, Chitayat D, Gourdon G, Thornton CA \& Pearson CE 2011 Expanded CTG repeat demarcates a boundary for abnormal CpG methylation in myotonic dystrophy patient tissues. Human Molecular Genetics 20 1-15. (https://doi. org $/ 10.1093 / \mathrm{hmg} / \mathrm{ddq} 427$ )

Luo H, Wang F, Zha J, Li H, Yan B, Du Q, Yang F, Sobh A, Vulpe C, Drusbosky L, et al. 2018 CTCF boundary remodels chromatin domain and drives aberrant HOX gene transcription in acute myeloid leukemia. Blood 132 837-848. (https://doi.org/10.1182/ blood-2017-11-814319)

Lupianez DG, Kraft K, Heinrich V, Krawitz P, Brancati F, Klopocki E, Horn D, Kayserili H, Opitz JM, Laxova R, et al. 2015 Disruptions of topological chromatin domains cause pathogenic rewiring of geneenhancer interactions. Cell 161 1012-1025. (https://doi. org/10.1016/j.cell.2015.04.004)

Majumder P \& Boss JM 2010 CTCF controls expression and chromatin architecture of the human major histocompatibility complex class II locus. Molecular \& Cellular Biology 30 4211-4223. (https://doi. org/10.1128/MCB.00327-10)

Majumder P, Gomez JA, Chadwick BP \& Boss JM 2008 The insulator factor CTCF controls MHC class II gene expression and is required for the formation of long-distance chromatin interactions. Journal of Experimental Medicine 205 785-798. (https://doi.org/10.1084/ jem.20071843)

Marques M, Hernandez RP \& Witcher M 2015 Analysis of changes to mRNA levels and CTCF occupancy upon TFII-I knockdown. Genomics Data 4 17-21. (https://doi.org/10.1016/j. gdata.2014.09.012)

Martin-Garcia D, Navarro A, Valdés-Mas R, Clot G, Gutiérrez-Abril J, Prieto M, Ribera-Cortada I, Woroniecka R, Rymkiewicz G, Bens S, et al. 2019 CCND2 and CCND3 hijack immunoglobulin light-chain enhancers in cyclin D1(-) mantle cell lymphoma. Blood 133 940-951. (https://doi.org/10.1182/blood-2018-07-862151)

Martin-Kleiner I 2012 BORIS in human cancers -- a review. European Journal of Cancer 48 929-935. (https://doi.org/10.1016/j. ejca.2011.09.009)

Matthews BJ \& Waxman DJ 2018 Computational prediction of CTCF/ cohesin-based intra-TAD loops that insulate chromatin contacts and gene expression in mouse liver. eLife 7 e34077. (https://doi. org/10.7554/eLife.34077)

McHugh CA, Chen CK, Chow A, Surka CF, Tran C, McDonel P, PandyaJones A, Blanco M, Burghard C, Moradian A, et al. 2015 The Xist IncRNA interacts directly with SHARP to silence transcription through HDAC3. Nature 521 232-236. (https://doi.org/10.1038/ nature14443)

Mei S, Ke J, Tian J, Ying P, Yang N, Wang X, Zou D, Peng X, Yang Y, Zhu Y, et al. 2019 A functional variant in the boundary of a topological association domain is associated with pancreatic cancer risk. Molecular Carcinogenesis 58 1855-1862. (https://doi.org/10.1002/ mc.23077)

Mondal G, Stevers M, Goode B, Ashworth A \& Solomon DA 2019 A requirement for STAG2 in replication fork progression creates a targetable synthetic lethality in cohesin-mutant cancers. Nature Communications 10 1686. (https://doi.org/10.1038/s41467-01909659-z)

Mora A, Sandve GK, Gabrielsen OS \& Eskeland R 2016 In the loop: promoter-enhancer interactions and bioinformatics. Briefings in Bioinformatics 17 980-995. (https://doi.org/10.1093/bib/bbv097)

Morita M, Shimokawa K, Nishimura M, Nakamura S, Tsujimura Y, Takemoto S, Tawara T, Yokota H, Wemler S, Miyamoto D, et al. 2019 https://erc.bioscientifica.com

https://doi.org/10.1530/ERC-19-0348 (c) 2019 Society for Endocrinology Published by Bioscientifica Ltd. Printed in Great Britain 
ViBrism DB: an interactive search and viewer platform for 2D/3D anatomical images of gene expression and co-expression networks. Nucleic Acids Research 47 D859-D866. (https://doi.org/10.1093/nar/ gky951)

Murakawa Y, Yoshihara M, Kawaji H, Nishikawa M, Zayed H, Suzuki H, Fantom C \& Hayashizaki Y 2016 Enhanced identification of transcriptional enhancers provides mechanistic insights into diseases. Trends in Genetics 32 76-88. (https://doi.org/10.1016/j. tig.2015.11.004)

Narendra V, Rocha PP, An D, Raviram R, Skok JA, Mazzoni EO \& Reinberg D 2015 CTCF establishes discrete functional chromatin domains at the Hox clusters during differentiation. Science $\mathbf{3 4 7}$ 1017-1021. (https://doi.org/10.1126/science.1262088)

Negi S, Bolt CC, Zhang H \& Stubbs L 2019 An extended regulatory landscape drives Tbx18 activity in a variety of prostate-associated cell lineages. Developmental Biology 446 180-192. (https://doi. org/10.1016/j.ydbio.2018.11.023)

Nora EP, Lajoie BR, Schulz EG, Giorgetti L, Okamoto I, Servant N, Piolot T, van Berkum NL, Meisig J, Sedat J, et al. 2012 Spatial partitioning of the regulatory landscape of the X-inactivation centre. Nature 485 381-385. (https://doi.org/10.1038/nature11049)

Northcott PA, Lee C, Zichner T, Stütz AM, Erkek S, Kawauchi D, Shih DJ, Hovestadt V, Zapatka M, Sturm D, et al. 2014 Enhancer hijacking activates GFI1 family oncogenes in medulloblastoma. Nature $\mathbf{5 1 1}$ 428-434. (https://doi.org/10.1038/nature13379)

Olender T, Keydar I, Pinto JM, Tatarskyy P, Alkelai A, Chien MS, Fishilevich S, Restrepo D, Matsunami H, Gilad Y, et al. 2016 The human olfactory transcriptome. BMC Genomics 17 619. (https://doi. org/10.1186/s12864-016-2960-3)

Olivier M, Aggarwal A, Allen J, Almendras AA, Bajorek ES, Beasley EM, Brady SD, Bushard JM, Bustos VI, Chu A, et al. 2001 A highresolution radiation hybrid map of the human genome draft sequence. Science 291 1298-1302. (https://doi.org/10.1126/ science.1057437)

Parolia A, Cieslik M \& Chinnaiyan AM 2018 Competing for enhancers: PVT1 fine-tunes MYC expression. Cell Research 28 785-786. (https:// doi.org/10.1038/s41422-018-0064-0)

Patten DK, Corleone G, Győrffy B, Perone Y, Slaven N, Barozzi I, Erdős E, Saiakhova A, Goddard K, Vingiani A, et al. 2018 Enhancer mapping uncovers phenotypic heterogeneity and evolution in patients with luminal breast cancer. Nature Medicine 24 1469-1480. (https://doi. org/10.1038/s41591-018-0091-x)

Peng WX, He RZ, Zhang Z, Yang L \& Mo YY 2019 LINC00346 promotes pancreatic cancer progression through the CTCF-mediated Myc transcription. Oncogene [epub]. (https://doi.org/10.1038/s41388-0190918-z)

Petrovic J, Zhou Y, Fasolino M, Goldman N, Schwartz GW, Mumbach MR, Nguyen SC, Rome KS, Sela Y, Zapataro Z, et al. 2019 Oncogenic Notch promotes long-range regulatory interactions within hyperconnected 3D cliques. Molecular Cell 73 1174-1190.e12. (https://doi.org/10.1016/j.molcel.2019.01.006)

Poterlowicz K, Yarker JL, Malashchuk I, Lajoie BR, Mardaryev AN, Gdula MR, Sharov AA, Kohwi-Shigematsu T, Botchkarev VA \& Fessing MY 2017 5C analysis of the epidermal differentiation complex locus reveals distinct chromatin interaction networks between gene-rich and gene-poor TADs in skin epithelial cells. PLOS Genetics 13 e1006966. (https://doi.org/10.1371/journal. pgen.1006966)

Pugacheva EM, Tiwari VK, Abdullaev Z, Vostrov AA, Flanagan PT, Quitschke WW, Loukinov DI, Ohlsson R \& Lobanenkov VV 2005 Familial cases of point mutations in the XIST promoter reveal a correlation between CTCF binding and pre-emptive choices of X chromosome inactivation. Human Molecular Genetics 14 953-965. (https://doi.org/10.1093/hmg/ddi089)

Racko D, Benedetti F, Dorier J \& Stasiak A 2018 Transcription-induced supercoiling as the driving force of chromatin loop extrusion during formation of TADs in interphase chromosomes. Nucleic Acids Research 46 1648-1660. (https://doi.org/10.1093/nar/gkx1123)

Racko D, Benedetti F, Dorier J \& Stasiak A 2019 Are TADs supercoiled? Nucleic Acids Research 47 521-532. (https://doi.org/10.1093/nar/ gky1091)

Razavi P, Chang MT, Xu G, Bandlamudi C, Ross DS, Vasan N, Cai Y, Bielski CM, Donoghue MTA, Jonsson P, et al. 2018 The genomic landscape of endocrine-resistant advanced breast cancers. Cancer Cell 34 427-438.e6. (https://doi.org/10.1016/j.ccell.2018.08.008)

Ren X, Cao D, Yang L, Li X, Zhang W, Xiao Y, Xi Y, Li F, Li D \& Pan Z 2019 High Expression of long non-coding RNA PVT1 predicts metastasis in Han and Uygur patients with gastric cancer in Xinjiang, China. Scientific Reports 9 548. (https://doi.org/10.1038/ s41598-018-36985-x)

Renaud S, Loukinov D, Alberti L, Vostrov A, Kwon YW, Bosman FT, Lobanenkov V \& Benhattar J 2011 BORIS/CTCFL-mediated transcriptional regulation of the hTERT telomerase gene in testicular and ovarian tumor cells. Nucleic Acids Research 39 862-873. (https:// doi.org/10.1093/nar/gkq827)

Rickman DS, Chen YB, Banerjee S, Pan Y, Yu J, Vuong T, Perner S, Lafargue CJ, Mertz KD, Setlur SR, et al. 2010 ERG cooperates with androgen receptor in regulating trefoil factor 3 in prostate cancer disease progression. Neoplasia 12 1031-1040. (https://doi. org/10.1593/neo.10866)

Rickman DS, Soong TD, Moss B, Mosquera JM, Dlabal J, Terry S, MacDonald TY, Tripodi J, Bunting K, Najfeld V, et al. 2012 Oncogene-mediated alterations in chromatin conformation. PNAS 109 9083-9088. (https://doi.org/10.1073/pnas.1112570109)

Roadmap Epigenomics Consortium, Kundaje A, Meuleman W, Ernst J, Bilenky M, Yen A, Heravi-Moussavi A, Kheradpour P, Zhang Z, Wang J, et al 2015 Integrative analysis of 111 reference human epigenomes. Nature 518 317-330. (https://doi.org/10.1038/ nature14248)

Roberts L, Davenport RJ, Pennisi E \& Marshall E 2001 A history of the Human Genome Project. Science 291 1195. (https://doi.org/10.1126/ science.291.5507.1195)

Robinson JT, Turner D, Durand NC, Thorvaldsdottir H, Mesirov JP \& Aiden EL 2018 Juicebox.js provides a cloud-based visualization system for Hi-C data. Cell Systems 6 256-258.e1. (https://doi. org/10.1016/j.cels.2018.01.001)

Rodriguez-Carballo E, Lopez-Delisle L, Zhan Y, Fabre PJ, Beccari L, El-Idrissi I, Huynh THN, Ozadam H, Dekker J \& Duboule D 2017 The HoxD cluster is a dynamic and resilient TAD boundary controlling the segregation of antagonistic regulatory landscapes. Genes \& Development 31 2264-2281. (https://doi.org/10.1101/ gad.307769.117)

Romero-Perez L, Surdez D, Brunet E, Delattre O \& Grunewald TGP 2019 STAG mutations in cancer. Trends in Cancer 5 506-520. (https://doi. org/10.1016/j.trecan.2019.07.001)

Ron G, Globerson Y, Moran D \& Kaplan T 2017 Promoter-enhancer interactions identified from Hi-C data using probabilistic models and hierarchical topological domains. Nature Communications 82237. (https://doi.org/10.1038/s41467-017-02386-3)

Rowley MJ \& Corces VG 2018 Organizational principles of 3D genome architecture. Nature Reviews. Genetics 19 789-800. (https://doi. org/10.1038/s41576-018-0060-8)

Roy SS, Mukherjee AK \& Chowdhury S 2018 Insights about genome function from spatial organization of the genome. Human Genomics 12 8. (https://doi.org/10.1186/s40246-018-0140-z)

Ryan RJ, Drier Y, Whitton H, Cotton MJ, Kaur J, Issner R, Gillespie S, Epstein CB, Nardi V, Sohani AR, et al. 2015 Detection of enhancerassociated rearrangements reveals mechanisms of oncogene dysregulation in B-cell lymphoma. Cancer Discovery 5 1058-1071. (https://doi.org/10.1158/2159-8290.CD-15-0370)

Saiki RK, Gelfand DH, Stoffel S, Scharf SJ, Higuchi R, Horn GT, Mullis KB \& Erlich HA 1988 Primer-directed enzymatic amplification https://erc bioscientifica com

https://doi.org/10.1530/ERC-19-0348 (c) 2019 Society for Endocrinology Published by Bioscientifica Ltd. Printed in Great Britain 
of DNA with a thermostable DNA polymerase. Science 239 487-491. (https://doi.org/10.1126/science.2448875)

Sanda MG, Feng Z, Howard DH, Tomlins SA, Sokoll LJ, Chan DW, Regan MM, Groskopf J, Chipman J, Patil DH, et al. 2017 Association between combined TMPRSS2:ERG and PCA3 RNA urinary testing and detection of aggressive prostate cancer. JAMA Oncology 3 10851093. (https://doi.org/10.1001/jamaoncol.2017.0177)

Sanli K, Karlsson FH, Nookaew I \& Nielsen J 2013 FANTOM: functional and taxonomic analysis of metagenomes. BMC Bioinformatics $\mathbf{1 4} 38$. (https://doi.org/10.1186/1471-2105-14-38)

Sanyal A, Lajoie BR, Jain G \& Dekker J 2012 The long-range interaction landscape of gene promoters. Nature 489 109-113. (https://doi. org/10.1038/nature11279)

Sauerwald N, Zhang S, Kingsford C \& Bahar I 2017 Chromosomal dynamics predicted by an elastic network model explains genomewide accessibility and long-range couplings. Nucleic Acids Research 45 3663-3673. (https://doi.org/10.1093/nar/gkx172)

Schmidl C, Renner K, Peter K, Eder R, Lassmann T, Balwierz PJ, Itoh M, Nagao-Sato S, Kawaji H, Carninci P, et al. 2014 Transcription and enhancer profiling in human monocyte subsets. Blood 123 e90-e99. (https://doi.org/10.1182/blood-2013-02-484188)

Shin HY 2019 The structural and functional roles of CTCF in the regulation of cell type-specific and human disease-associated superenhancers. Genes \& Genomics 41 257-265. (https://doi.org/10.1007/ s13258-018-0768-z)

Shin H, Shi Y, Dai C, Tjong H, Gong K, Alber F \& Zhou XJ 2016 TopDom: an efficient and deterministic method for identifying topological domains in genomes. Nucleic Acids Research 44 e70. (https://doi.org/10.1093/nar/gkv1505)

Sima J, Chakraborty A, Dileep V, Michalski M, Klein KN, Holcomb NP, Turner JL, Paulsen MT, Rivera-Mulia JC, Trevilla-Garcia C, et al. 2019 Identifying cis elements for spatiotemporal control of mammalian DNA replication. Cell 176 816-830.e18. (https://doi.org/10.1016/j. cell.2018.11.036)

Smith ST, Wickramasinghe P, Olson A, Loukinov D, Lin L, Deng J, Xiong Y, Rux J, Sachidanandam R, Sun H, et al. 2009 Genome wide ChIP-chip analyses reveal important roles for CTCF in Drosophila genome organization. Developmental Biology 328 518-528. (https:// doi.org/10.1016/j.ydbio.2008.12.039)

Spencer RJ, del Rosario BC, Pinter SF, Lessing D, Sadreyev RI \& LEE JT 2011 A boundary element between Tsix and Xist binds the chromatin insulator ctcf and contributes to initiation of X-chromosome inactivation. Genetics 189 441-454. (https://doi. org/10.1534/genetics.111.132662)

Spielmann M, Lupianez DG \& Mundlos S 2018 Structural variation in the 3D genome. Nature Reviews. Genetics 19 453-467. (https://doi. org/10.1038/s41576-018-0007-0)

Splinter E, Heath H, Kooren J, Palstra RJ, Klous P, Grosveld F, Galjart N \& de Laat W 2006 CTCF mediates long-range chromatin looping and local histone modification in the beta-globin locus. Genes \& Development 20 2349-2354. (https://doi.org/10.1101/gad.399506)

Stansfield JC, Cresswell KG \& Dozmorov MG 2019 multiHiCcompare: joint normalization and comparative analysis of complex Hi-C experiments. Bioinformatics 35 2916-2923. (https://doi.org/10.1093/ bioinformatics/btz048)

Strom AR, Emelyanov AV, Mir M, Fyodorov DV, Darzacq X \& Karpen GH 2017 Phase separation drives heterochromatin domain formation. Nature 547 241-245. (https://doi.org/10.1038/nature22989)

Symmons O, Uslu VV, Tsujimura T, Ruf S, Nassari S, Schwarzer W, Ettwiller L \& Spitz F 2014 Functional and topological characteristics of mammalian regulatory domains. Genome Research 24 390-400. (https://doi.org/10.1101/gr.163519.113)

Taberlay PC, Statham AL, Kelly TK, Clark SJ \& Jones PA 2014 Reconfiguration of nucleosome-depleted regions at distal regulatory elements accompanies DNA methylation of enhancers and insulators in cancer. Genome Research 24 1421-1432. (https://doi.org/10.1101/ gr.163485.113)

Taberlay PC, Achinger-Kawecka J, Lun AT, Buske FA, Sabir K, Gould CM, Zotenko E, Bert SA, Giles KA, Bauer DC, et al. 2016 Threedimensional disorganization of the cancer genome occurs coincident with long-range genetic and epigenetic alterations. Genome Research 26 719-731. (https://doi.org/10.1101/gr.201517.115)

Taslim C, Chen Z, Huang K, Huang TH, Wang Q \& Lin S 2012 Integrated analysis identifies a class of androgen-responsive genes regulated by short combinatorial long-range mechanism facilitated by CTCF. Nucleic Acids Research $\mathbf{4 0}$ 4754-4764. (https://doi. org/10.1093/nar/gks139)

Tomlins SA, Rhodes DR, Perner S, Dhanasekaran SM, Mehra R, Sun XW, Varambally S, Cao X, Tchinda J, Kuefer R, et al. 2005 Recurrent fusion of TMPRSS2 and ETS transcription factor genes in prostate cancer. Science 310 644-648. (https://doi.org/10.1126/ science.1117679)

Tomlins SA, Day JR, Lonigro RJ, Hovelson DH, Siddiqui J, Kunju LP, Dunn RL, Meyer S, Hodge P, Groskopf J, et al. 2016 Urine TMPRSS2:ERG plus PCA3 for individualized prostate cancer risk assessment. European Urology 70 45-53. (https://doi.org/10.1016/j. eururo.2015.04.033)

Tsai YC, Cooke NE \& Liebhaber SA 2014 Tissue specific CTCF occupancy and boundary function at the human growth hormone locus. Nucleic Acids Research 42 4906-4921. (https://doi.org/10.1093/nar/gku139)

Tsai YC, Cooke NE \& Liebhaber SA 2016 Long-range looping of a locus control region drives tissue-specific chromatin packing within a multigene cluster. Nucleic Acids Research 44 4651-4664. (https://doi. org/10.1093/nar/gkw090)

Tsui S, Gao J, Wang C \& LU L 2012 CTCF mediates effect of insulin on glucagon expression. Experimental Cell Research 318 887-895. (https://doi.org/10.1016/j.yexcr.2012.03.001)

Ulz P, Belic J, Graf R, Auer M, Lafer I, Fischereder K, Webersinke G, Pummer K, Augustin H, Pichler M, et al. 2016 Whole-genome plasma sequencing reveals focal amplifications as a driving force in metastatic prostate cancer. Nature Communications 7 12008. (https:// doi.org/10.1038/ncomms12008)

Unkeless JC 1989 Human Fc receptors for IgG. International Reviews of Immunology 5 165-171. (https://doi. org/10.3109/08830188909061983)

Wang YL \& Taylor DL 1979 Distribution of fluorescently labeled actin in living sea urchin eggs during early development. Journal of Cell Biology 81 672-679. (https://doi.org/10.1083/jcb.81.3.672)

Wang J, Cai Y, Shao LJ, Siddiqui J, Palanisamy N, Li R, Ren C, Ayala G \& Ittmann M 2011 Activation of NF-\{kappa\}B by TMPRSS2/ERG fusion isoforms through Toll-like receptor-4. Cancer Research 71 1325-1333. (https://doi.org/10.1158/0008-5472.CAN-10-2210)

Wang H, Maurano MT, Qu H, Varley KE, Gertz J, Pauli F, Lee K, Canfield T, Weaver M, Sandstrom R, et al. 2012a Widespread plasticity in CTCF occupancy linked to DNA methylation. Genome Research 22 1680-1688. (https://doi.org/10.1101/gr.136101.111)

Wang J, Wang Y \& Lu L $2012 b$ De-SUMOylation of CCCTC binding factor (CTCF) in hypoxic stress-induced human corneal epithelial cells. Journal of Biological Chemistry 287 12469-12479. (https://doi. org/10.1074/jbc.M111.286641)

Wang S, Kollipara RK, Srivastava N, Li R, Ravindranathan P, Hernandez E, Freeman E, Humphries CG, Kapur P, Lotan Y, et al. 2014 Ablation of the oncogenic transcription factor ERG by deubiquitinase inhibition in prostate cancer. PNAS 111 4251-4256. (https://doi.org/10.1073/pnas.1322198111)

Wang Y, Song F, Zhang B, Zhang L, Xu J, Kuang D, Li D, Choudhary MNK, Li Y, Hu M, et al. 2018 The 3D Genome Browser: a web-based browser for visualizing 3D genome organization and long-range chromatin interactions. Genome Biology 19 151. (https:// doi.org/10.1186/s13059-018-1519-9) (c) 2019 Society for Endocrinology Published by Bioscientifica Ltd. Printed in Great Britain 
Wang DC, Wang W, Zhang L \& Wang X 2019 A tour of 3D genome with a focus on CTCF. Seminars in Cell \& Developmental Biology 90 4-11. (https://doi.org/10.1016/j.semcdb.2018.07.020)

Weaver W 1970 Molecular biology: origin of the term. Science 170 581-582. (https://doi.org/10.1126/science.170.3958.581-a)

Weischenfeldt J, Dubash T, Drainas AP, Mardin BR, Chen Y, Stütz AM, Waszak SM, Bosco G, Halvorsen AR, Raeder B, et al. 2017 Pan-cancer analysis of somatic copy-number alterations implicates IRS4 and IGF2 in enhancer hijacking. Nature Genetics 49 65-74. (https://doi. org/10.1038/ng.3722)

Wendt KS, Yoshida K, Itoh T, Bando M, Koch B, Schirghuber E, Tsutsumi S, Nagae G, Ishihara K, Mishiro T, et al. 2008 Cohesin mediates transcriptional insulation by CCCTC-binding factor. Nature 451 796-801. (https://doi.org/10.1038/nature06634)

Wolfsberg TG, Mcentyre J \& Schuler GD 2001 Guide to the draft human genome. Nature 409 824-826. (https://doi.org/10.1038/35057000)

Woloszynska-Read A, Zhang W, Yu J, Link PA, Mhawech-Fauceglia P, Collamat G, Akers SN, Ostler KR, Godley LA, Odunsi K, et al. 2011 Coordinated cancer germline antigen promoter and global DNA hypomethylation in ovarian cancer: association with the BORIS/ CTCF expression ratio and advanced stage. Clinical Cancer Research 17 2170-2180. (https://doi.org/10.1158/1078-0432.CCR-10-2315)

Wright FA, Lemon WJ, Zhao WD, Sears R, Zhuo D, Wang JP, Yang HY, Baer T, Stredney D, Spitzner J, et al. 2001 A draft annotation and overview of the human genome. Genome Biology 2 research0025. (https://doi.org/10.1186/gb-2001-2-7-research0025)

Wu P, Li T, Li R, Jia L, Zhu P, Liu Y, Chen Q, Tang D, Yu Y \& Li C 2017 $3 \mathrm{D}$ genome of multiple myeloma reveals spatial genome disorganization associated with copy number variations. Nature Communications 8 1937. (https://doi.org/10.1038/s41467-017-01793-w)
Yamamoto S, Wu Z, Russnes HG, Takagi S, Peluffo G, Vaske C, Zhao X, Moen Vollan HK, Maruyama R, Ekram MB, et al. 2014 JARID1B is a luminal lineage-driving oncogene in breast cancer. Cancer Cell 25 762-777. (https://doi.org/10.1016/j. ccr.2014.04.024)

Yang F, Deng X, Ma W, Berletch JB, Rabaia N, Wei G, Moore JM, Filippova GN, Xu J, Liu Y, et al. 2015 The lncRNA Firre anchors the inactive $\mathrm{X}$ chromosome to the nucleolus by binding CTCF and maintains H3K27me3 methylation. Genome Biology 16 52. (https:// doi.org/10.1186/s13059-015-0618-0)

Yauy K, Gatinois V, Guignard T, Sati S, Puechberty J, Gaillard JB, Schneider A \& Pellestor F 2018 Looking for broken TAD boundaries and changes on DNA interactions: clinical guide to 3D chromatin change analysis in complex chromosomal rearrangements and chromothripsis. Methods in Molecular Biology 1769 353-361. (https:// doi.org/10.1007/978-1-4939-7780-2_22)

Zhang Y, Liang J, Li Y, Xuan C, Wang F, Wang D, Shi L, Zhang D \& Shang Y 2010 CCCTC-binding factor acts upstream of FOXA1 and demarcates the genomic response to estrogen. Journal of Biological Chemistry 285 28604-28613. (https://doi.org/10.1074/jbc. M110.149658)

Zhang R, Wang Y, Yang Y, Zhang Y \& Ma J 2018 Predicting CTCFmediated chromatin loops using CTCF-MP. Bioinformatics 34 i133-i141. (https://doi.org/10.1093/bioinformatics/bty248)

Zimmerman MW, Liu Y, He S, Durbin AD, Abraham BJ, Easton J, Shao Y, $\mathrm{Xu}$ B, Zhu S, Zhang X, et al. 2018 MYC drives a subset of high-risk pediatric neuroblastomas and is activated through mechanisms including enhancer hijacking and focal enhancer amplification. Cancer Discovery 8 320-335. (https://doi.org/10.1158/2159-8290. CD-17-0993)

Received in final form 23 August 2019

Accepted 9 September 2019

Accepted Preprint published online 9 September 2019 (c) 2019 Society for Endocrinology Published by Bioscientifica Ltd. Printed in Great Britain 